\title{
Stratigraphical and morphological aspects of the northern Marmara shelf based on seismic data
}

\author{
Aslihan Nasif ${ }^{1, *}$, Derman Dondurur ${ }^{1}$ and Denizhan Vardar ${ }^{2}$ \\ ${ }^{1}$ Institute of Marine Sciences and Technology, Dokuz Eylül University, Baku Street, No. 100, \\ 35340 Inciralt, İzmir, Turkey. \\ ${ }^{2}$ Institute of Marine Sciences and Management, Istanbul University, Müşküle Sok. No. 17, \\ 34134 Fatih, Istanbul, Turkey. \\ *Corresponding author. e-mail: aslihan.nasif@deu.edu.tr
}

MS received 19 October 2017; revised 9 April 2018; accepted 16 June 2018; published online 25 February 2019

Recent sedimentation and Plio-Quaternary stratigraphy of northern Marmara shelf has been investigated by high-resolution seismic datasets. Seismic data indicate that a thin cover of Plio-Quaternary unit (termed Unit 1) overlies the Miocene/Oligocene age older sediments (termed Unit 2). The erosional surface between Unit 1 and Unit 2 is the regional unconformity for the shelf formed during the last sea level low stand. Unit 1 is subdivided into two sub-units as Unit 1a for Holocene deposits accumulated after the last glacial maximum (LGM) and Unit 1b for fluvial sediments deposited during the last low stand of the Marmara Sea. The thickness of the Holocene sediments is maximum at SW of Bosphorus outlet, in the Büyükçekmece Bay and along the coastal area between Silivri and Büyükçekmece reaching approximately $32 \mathrm{~m}$. Mean sedimentation rate of the entire northern shelf is calculated as $0.4 \mathrm{~m} / 1000$ yr for the last 12,000 yr based on the Holocene sediment thickness. There are four depressions in the western part of the shelf, which correspond to palaeolakes during the LGM filled by Plio-Quaternary sediments. Transition from lacustrine to marine conditions in the palaeolakes occurred when the Marmara Sea level exceeded $-62 \mathrm{~m}$ threshold depth during the sea level rise following the LGM at approximately 12,500-13,000 yr before present (BP).

Keywords. Seismic stratigraphy; Neogene-Quaternary sedimentation; palaeolakes; Marmara Sea.

\section{Introduction}

Marmara is an inland sea constituting the oceanographic connection between the Black Sea and Aegean Sea via two shallow gateways, Bosphorus and Dardanelles straits. It has particular importance since it has a significant active structural element, the dextral North Anatolian Fault (NAF), which produced a number of destructive earthquakes in the last century, and therefore, it has drawn the attention of many researchers in the last two decades. Although there are several studies on the oceanographic conditions and tectonic structure of the Marmara, a limited number of studies exist on the relative sea level variations during the last glacial maximum (LGM) and their effects on the recent sedimentation on the shallow shelf areas.

Palaeoenvironmental evolution of the Marmara Sea along with the relative sea level variations within the Holocene is still controversial (e.g., Stanley and Blanpied 1980; Ryan et al. 1997; Çağatay et al. 2000; Görür et al. 2001; Hiscott and Aksu 2002; Hiscott et al. 2002, 2007a,b; 
Kaminski et al. 2002; Mudie et al. 2004). Relative sea level variations in the Marmara Sea are partly compatible with the glacial and inter-glacial periods, and these variations control the connection of the basin with the Black Sea and Aegean via Bosphorus and Dardanelles Straits, which have minimum sill depths of approximately -34 and $-70 \mathrm{~m}$ today, respectively (all the negative elevations are measured below the present-day sea level throughout the paper). Çağatay et al. (2009) claim that during MIS2, MIS3, MIS4 and MIS6 the Marmara evolved into a freshwater lake, while it reconnected with Mediterranean during MIS1, MIS5 and MIS7 and became salty again. At the beginning of MIS1, the last connection with Mediterranean was established as a result of a rapid sea level rise (Çağatay et al. 2000, 2003; Hiscott and Aksu 2002; Sperling et al. 2003; Polonia et al. 2004; Eriş et al. 2007).

Disconnection of the Marmara with the Black Sea and Mediterranean along with a dry climate, when the sea became lake, resulted in a forced regression in the Marmara during MIS3 and MIS2. At LGM, when the lake level was fixed at approximately $-90 \mathrm{~m}$, subaerial erosion occurred at the northern shelf because the river flows down to -105 $\mathrm{m}$ water depths. Post-glacial fresh water transgression stage of Marmara Lake formed 15,000 and 13,500 yr before present (BP), and, according to the wave-cut terraces at the northern shelf, it raised the water level to $-85 \mathrm{~m}$ at $13,000 \mathrm{yr} \mathrm{BP}$. The wave-cut terraces found at $-85 \mathrm{~m}$ water depth at the northern shelf are attributed to a stable lake level before the Holocene marine connection was established (Çăgatay et al. 2003, 2009; Polonia et al. 2004; Eriş et al. 2007).

At the end of LGM, Mediterranean waters flowed into the Black Sea via Marmara through Dardanelles and Bosphorus straits. The timing of this flood is controversial and is dated at a period between 9000 and 7500 yr BP (Ryan et al. 1997, 2003; Görür et al. 2001; Aksu et al. 2002a; Hiscott and Aksu 2002; Major et al. 2002; McHugh et al. 2008; Vidal et al. 2010). Present-day two-way flow within the Marmara Sea via the straits was formed 4500-5000 yr BP (Çă̆atay et al. 1999, 2000; Algan et al. 2001).

Most of the seismic data used to define the recent sedimentation in the northern shelf (Gökaşan et al. 2005; Eriş et al. 2007; Karakılçık et al. 2014; Tur et al. 2015) are of relatively low resolution and their spatial distribution along the shelf is generally not suitable for a detailed mapping of the shallow stratigraphy of the shelf. In this regard, the shallow stratigraphy and recent sedimentation of the area can be more precisely defined by high-resolution seismic data covering the whole shelf area. The main purpose of this study is to determine the late Pleistocene-Holocene stratigraphy, morphology and depositional environment of the northern Marmara shelf between Silivri and Bosphorus in detail by using high-resolution seismic dataset.

\section{Regional settings}

\subsection{Regional and geological background}

Marmara basin represents the offshore section of NW Anatolian graben system which is a result of interplay between the NAF and the extensional tectonic regime of the NW Anatolia (Görür et al. 1997). Intra-Pontid ocean gradually closed at the end of the Oligocene (Okay and Tansel 1994; Görür and Okay 1996) which resulted in a suture zone in the area where the Marmara resides today. In accordance with the uplift and erosional processes around the area, internal continental closure continued during the Early Miocene, and fluviolacustrine conditions prevailed in the Thrace Basin and Biga Peninsula during the Miocene (Görür et al. 1997). Mediterranean waters flowed into the Marmara Sea basin along the northern Marmara shelf via Saros graben between early Middle Miocene and early Late Miocene time (Şengör et al. 1985).

Marmara Sea morphologically consists of a 45km-wide southern shelf, 10-20-km-wide northern shelf and three basins aligned in the $\mathrm{E}-\mathrm{W}$ direction: Tekirdağ, Central and Çınarcık Basins from west to east with a maximum depth of $1250 \mathrm{~m}$ (figure 1). Two uplifts in NNE-SSW alignment termed Western and Central Ridges, located at 400 and $600 \mathrm{~m}$ water depths, respectively, separate the basins. This morphology resulted in the westernmost extension of NAF within the NW Anatolia (Taymaz et al. 1991). Çağatay et al. (2000) suggest that these basins consist of turbidities developed in a continuous manner within a slightly inclined platform except the areas affected by the faulting. Based on the sediment cores, mean sedimentation rates for shelves, ridges and basins are 40, 10 and 100-200 cm/1000 yr, respectively (Çağatay et al. 2000).

NAF is the most prominent structural element within the Marmara Sea, which widely affects the 


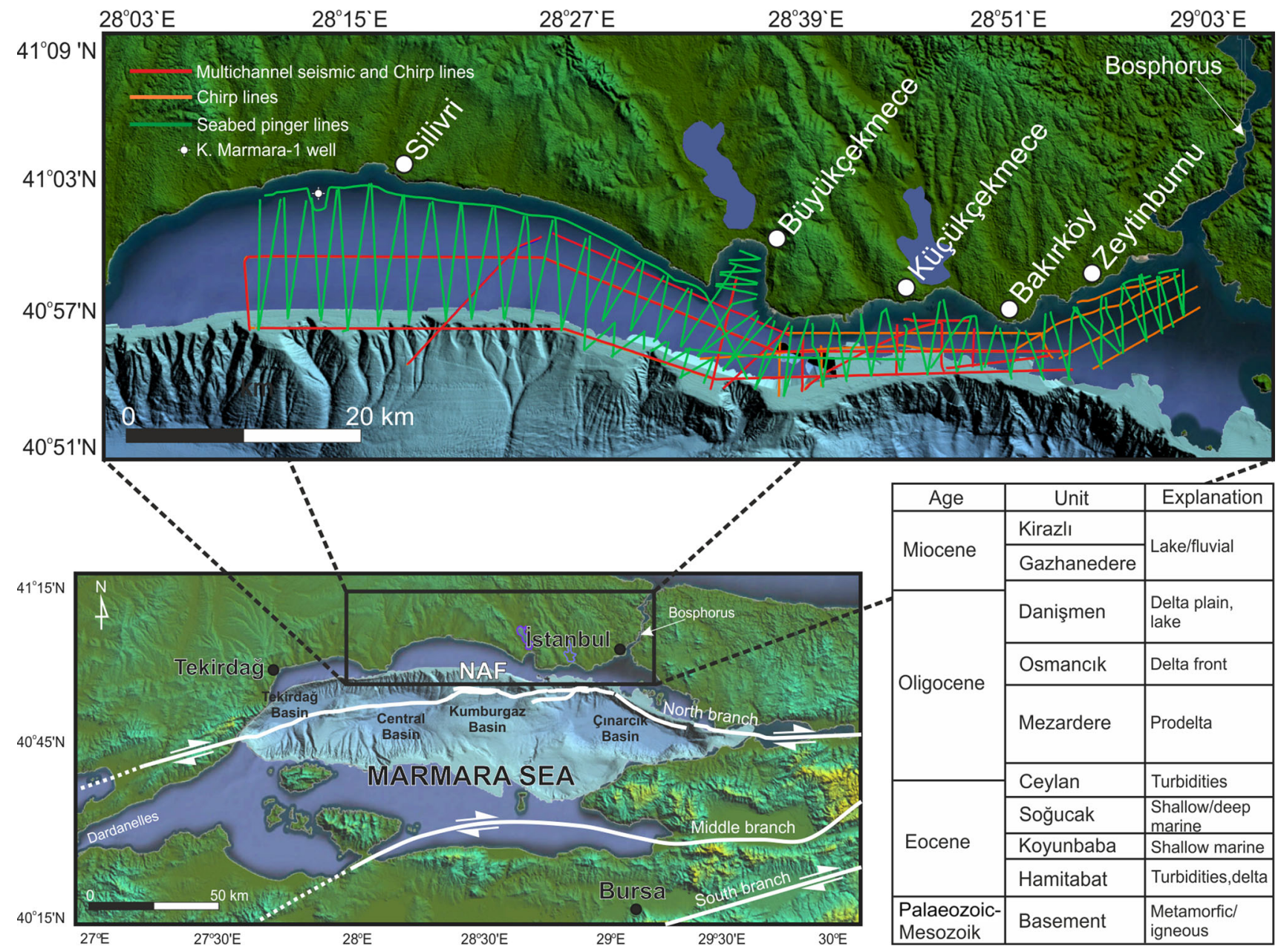

Figure 1. Location map of the study area and the seismic profiles. Simplified stratigraphic column of the northern Marmara shelf (S. Kasar, personal comm). NAF represents the North Anatolian Fault (Fault map is simplified from Yaltırak 2002.)

present-day structural and morphological setting of the deep basin (figure 1). NAF bifurcates into three branches to the east where it enters the Marmara Sea. All three branches have different kinematics and appearance on the seismic sections (Sarıtas 2013). The northern branch of the NAF is the westernmost termination area of this $>1100-\mathrm{km}$-long active fault which produced several destructive earthquakes of $>7.0 \mathrm{M}$ starting with a 7.9 M Erzincan earthquake in 1939 to the eastern part of Anatolia (Stein et al. 1997; Şengör et al. 2005). The last destructive one along the NAF was İzmit Earthquake $(7.4 \mathrm{M})$ which occurred in August 1999 and resulted in a 150-km-long rupture (Barka 2002).

Present-day tectonic structure of the Marmara Sea is investigated in terms of long and short period influences of the NAF on the deep basin. Several researchers suggested different tectonic models for the Marmara based on the regional seismic data, which can be grouped into three categories: (i) pull-apart models (e.g., Barka and Kadinsky-Cade 1988), (ii) models with en-echelon faulting (e.g., Parke et al. 1999; Okay et al. 2000) and (iii) master fault models (Aksu et al. 2000; İmren et al. 2001).

Görür et al. (1997) suggested that northern parts of the lacustrine Marmara Basin were flooded at the end of Middle Miocene or at the beginning of Late Miocene, through a narrow corridor from northern Aegean Sea to the northern Marmara shelf via Saros depression. In this period, shallow shelves of the Marmara Sea including wide southern shelf remained as land. During the Upper Miocene, connection with the Mediterranean was terminated, and the brackish waters of Paratethys flooded the Marmara Basin. In this period, southern shelf remained as land. Present-day structure of the Marmara Sea has settled at Middle and Late Pliocene. According to Tüysüz et al. (1998), NAF started to develop in Early Pliocene, and uplifted 
the Marmara Region at the beginning with a compressional effect; then, in the Late PleistoceneQuaternary period, the extensional tectonic regime responsible for the formation of Saros Bay and Marmara Sea developed.

Although the history of water exchange between Black Sea and Mediterranean goes back to 30,000 yr BP, uncertainties still exist about the connection. The oldest sediment fill overlying the Palaeozoic basement represents fresh water environment for 26,000 yr BP, and sediment cores indicate that these fresh water conditions lasted until 12,000 yr BP. During the LGM, connections of Marmara Sea with the Aegean and Black Seas at low-stand stages have been lost resulting in a lacustrine period. At this stage, Marmara was an enclosed basin, and the Black Sea became an anoxic basin due to the lack of water circulation via Bosphorus (Görür et al. 1997; Çağatay et al. 2000). Aksu et al. (2002b) define this period with an excessive water input from the Black Sea, which is attributed to the existence of the erosional surface on the seismic data (located between -95 and $-125 \mathrm{~m}$ water depths) collected from the continental shelf of the southern Black Sea.

\subsection{Study area}

The study area comprises almost entire of the narrow $(\sim 15 \mathrm{~km})$ northern shelf of the Marmara Sea between Silivri and Bosphorus (figure 1). The drainage basin is approximately $4438 \mathrm{~km}^{2}$ in the area, and has been fed by small rivers only without significant amount of discharge (Okay and Ergün 2005), while the discharge to the southern shelf extends into a $30,600 \mathrm{~km}^{2}$ area with a $6.3 \times 10^{6}$ tons per annum total sediment input (Ergin et al. 1991).

Main stratigratigraphic units of the northern shelf are shown in figure 1. Lithological units located onshore along the northern Marmara shelf are the sediments generally in Oligocene-Miocene age, which continue to the south to form the deeper stratigraphy of the northern shelf. Oligocene sediments consist of sandstone and shale, whereas the Miocene unit involves terrigenous clastics, lacustrine clay and marl (Siyako 2006). The Palaeozoic unit observed along the coastline involves terrigenous and shallow marine clastics and carbonates, deep marine shales and carbonates as well as flysch facies (Oktay et al. 2002), and constitutes the basement along the shelf.

\section{Data and methods}

Acoustic datasets used in this study were collected by Dokuz Eylül University, Institute of Marine Sciences and Technology in 2007, aboard the R/V K. Piri Reis research vessel during a specific project conducted by Marmara Research Center of the Scientific and Technological Research Council of Turkey (TÜBİTAK-MAM). A global Differential Global Positioning System (DGPS) with a horizontal error less than $1 \mathrm{~m}$ was used during the entire study.

In order to define the morphology, stratigraphy, recent sedimentation and structural state of the northern continental shelf of the Marmara Sea, $224 \mathrm{~km}$ of multichannel high-resolution seismic, 338 $\mathrm{km}$ of Chirp subbottom profiler and Seabed pinger data have been collected along the shelf (figure 1). A $600 \mathrm{~m}$ long, 96 channel digital seismic streamer with a $6.25 \mathrm{~m}$ group interval and a generatorinjector gun was used to obtain high-resolution seismic data. The recording length, sampling rate and shot interval were $3.0 \mathrm{~s}, 1.0 \mathrm{~ms}$ and $12.5 \mathrm{~m}$, respectively. The Chirp data were collected using an over-the-side-mount transducer system operating at $2.75-6.75 \mathrm{kHz}$ frequency band. The seabed pinger system was also over-the-side-mount operating at $3.5 \mathrm{kHz}$ frequency, and the recording length and sampling rate were 250 and $0.1 \mathrm{~ms}$, respectively.

The seismic data have been processed by a conventional processing flow which included geometry loading, band-pass filter, f-k filter, automatic gain control, surface related multiple elimination, velocity analysis, normal moveout correction/stack and Kirchhoff poststack time migration. The Chirp data were cross-correlated with the source signal to obtain the Klauder wavelet, then the envelope of the signal was calculated. Seabed pinger data were band-pass filtered $(2.5-5 \mathrm{kHz})$, gain recovery was applied and the envelope of the data were calculated.

Processed data were loaded into the interactive interpretation system to pick the possible faults, seafloor reflection to obtain the present-day seafloor morphology and other prominent reflections such as base of the Holocene sediments. Then the main stratigraphic units were picked from highresolution seismic data and their two-way arrival times were mapped. While the deeper stratigraphic correlations have been done using the information from K. Marmara-1 well located NW part of the study area, the post-Holocene stratigraphy 
was deduced from a careful jump correlation with previously published data for the shelf area.

\section{Results}

\subsection{Seafloor morphology}

According to the bathymetric map of the northern Marmara shelf generated from high-resolution seismic data (figure 2), the shelf is the widest at offshore Silivri reaching $12 \mathrm{~km}$ width. The width of the shelf gradually decreases towards the east and the narrowest shelf is $4.5 \mathrm{~km}$ offshore Zeytinburnu to the east. Except coastal areas shallower than approximately $15 \mathrm{~m}$ and the easternmost area located just western part of the Bosphorus outlet, entire shelf has a flat morphology with a very low bathymetric gradient, with a shelf break located approximately $90 \mathrm{~m}$ depth contour for whole northern Marmara. Seismic data from the shelf area cross-cutting the canyon heads indicate the possibility of strong erosion in these areas.

The study area is sub-divided into three regions depending on their different present-day morphology and recent sedimentation characteristics (figure 2): (i) western platform (between Silivri and Büyükçekmece Bay, (ii) central platform (between Büyükçekmece Bay and Bakırköy and (iii) eastern platform (between Bakırköy and Bosphorus outlet).

The western platform consisting of small-scale depressions in different sizes is defined as an almost flat surface of an erosional plane with relatively small amount of recent sediment accumulations. The width of this part of the shelf gets smaller towards the east reaching its minimum value at the western part of Büyükçekmece Bay. The central platform is approximately $24 \mathrm{~km}$ wide with a relatively higher bathymetric gradient with respect to the western platform, and it also comprises the submarine extensions of the slides that occurred along the coastline. Eastern border of the shelf is limited by a distinctive morphological structure located in the eastern platform which involves sandbars formed by the sediments transported via Bosphorus. Eastern platform receives the highest sediment input with respect to the other areas along the northern shelf.

\subsection{Systematic seismic facies analysis}

Recent sedimentation along the northern Marmara shelf after the Miocene has been investigated by high-resolution seismic dataset which has a maximum penetration of approximately $40 \mathrm{~m}$. Two seismic units separated by an unconformity surface are differentiated from the seismic data over the entire shelf, and are named as Unit 1 (U1) and Unit 2 (U2) from seafloor to deeper sediments, which represent Plio-Quaternary sediments and acoustic basement, respectively. U1 is further sub-divided into two units as Unit 1a (U1a) and Unit 1b (U1b) depending on their internal reflection characteristics and their depositional environments.

Figure 3 shows these units on different seismic lines from western, central and eastern platforms. Both units show different characteristics in different parts of the shelf: they are relatively thick in the west and east, while their thickness is significantly low in the central part. Figure 4 shows characteristics of both units and their general appearance on the seismic data. U1 consists of Plio-Quaternary sediments and $\mathrm{U} 2$ is the deepest unit on the

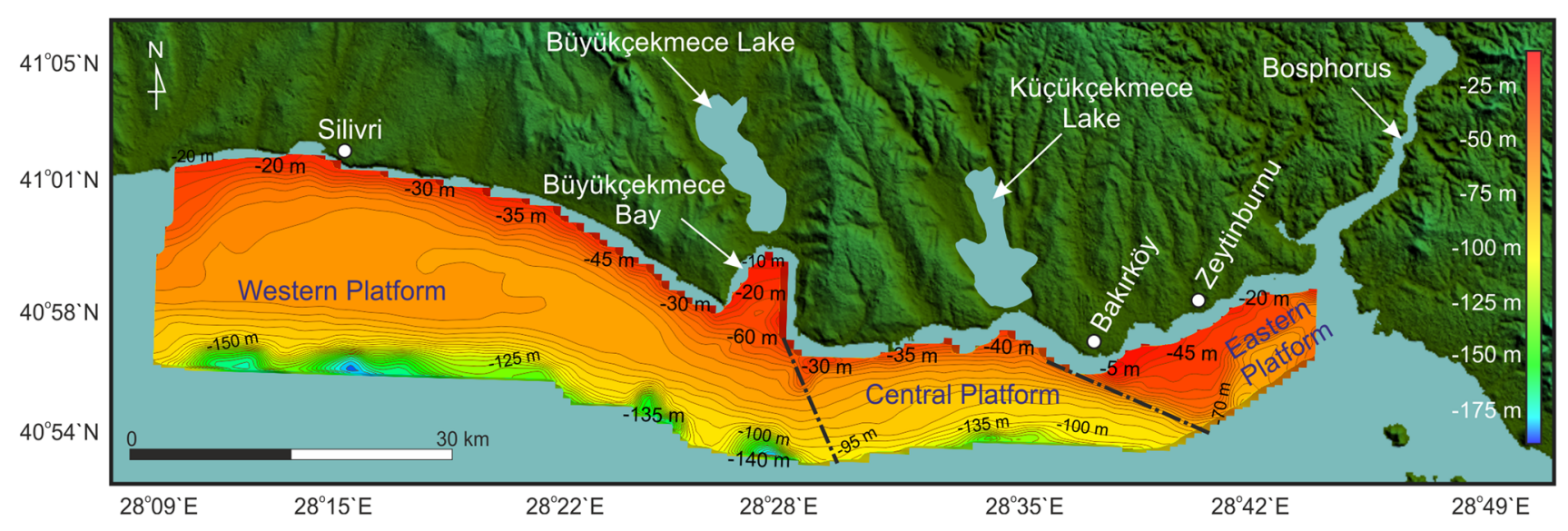

Figure 2. Bathymetric map of the northern Marmara shelf obtained from high-resolution seismic data. The shelf area is subdivided into three parts in terms of their morphological and structural context: the western, central and eastern platforms. 

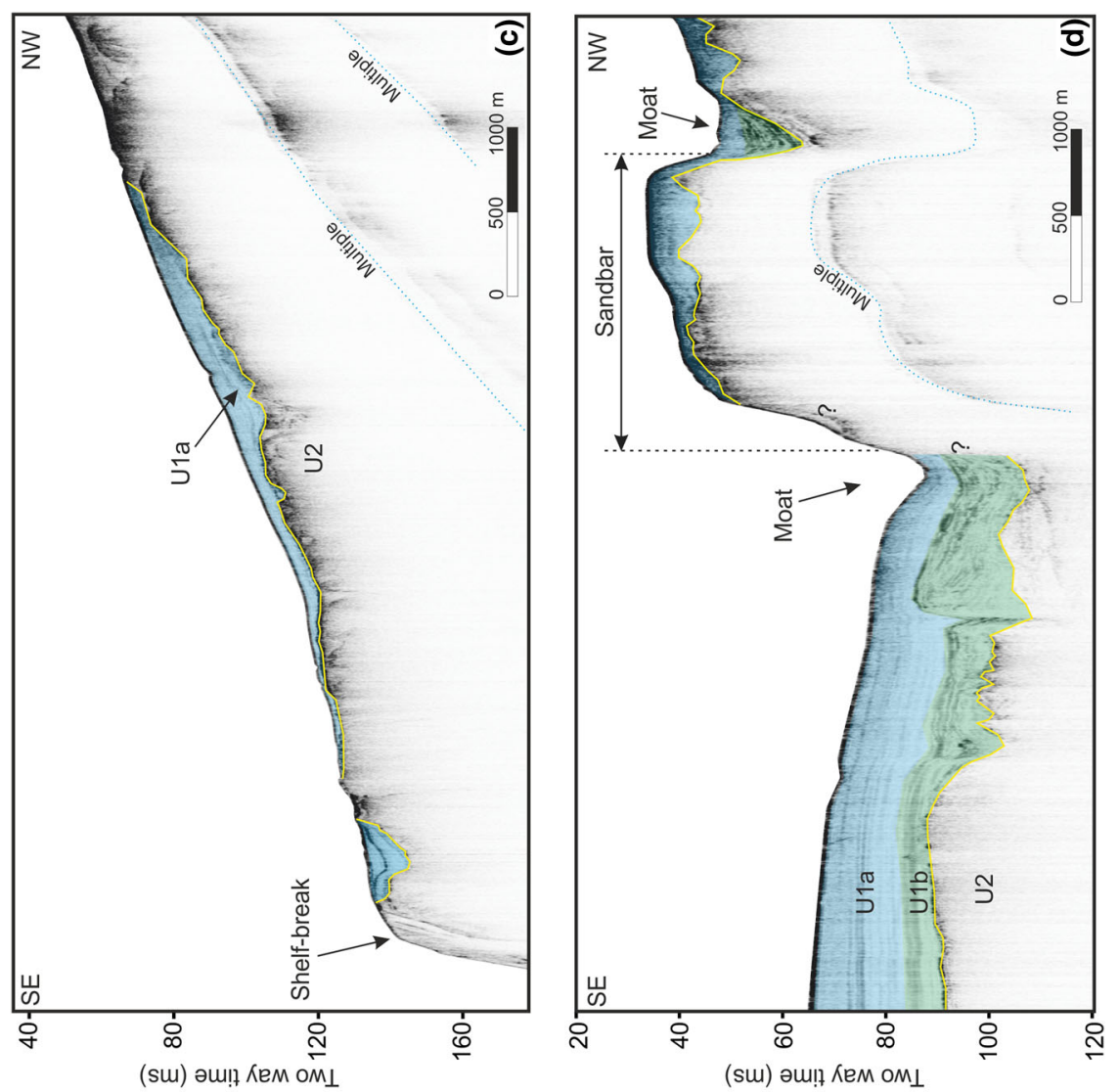

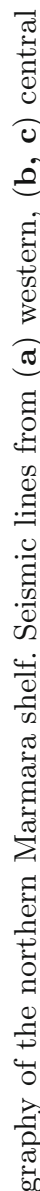
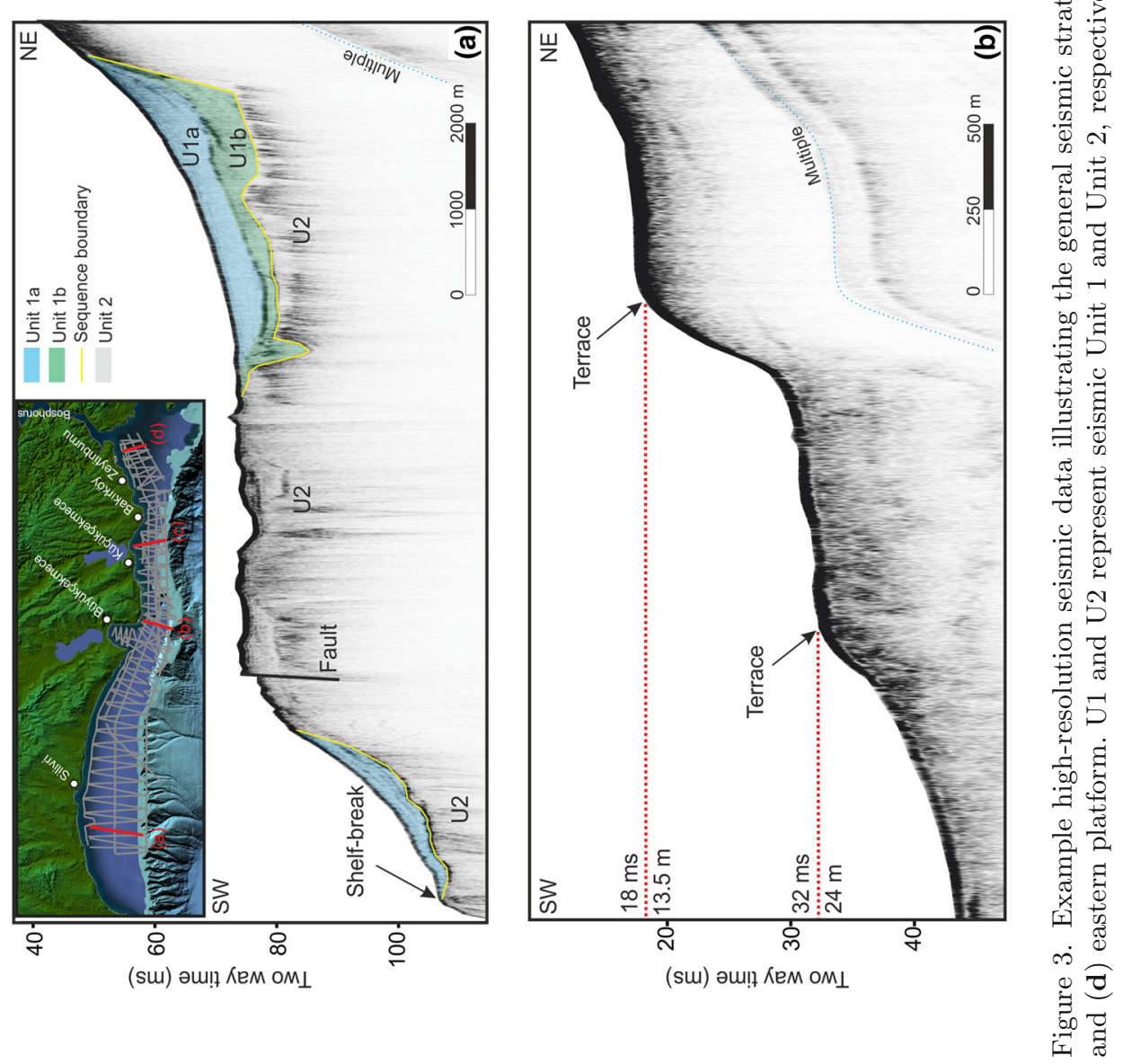


\begin{tabular}{|c|c|c|c|c|}
\hline Age & \multicolumn{2}{|c|}{ Unit } & Seismic Image & Definition \\
\hline \multirow{2}{*}{ 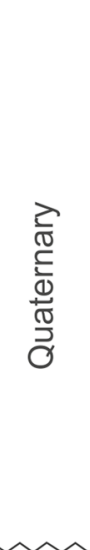 } & \multirow{2}{*}{ U1 } & U1a & 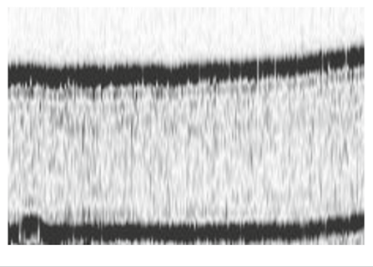 & $\begin{array}{l}\text { This is the topmost unit in the sedimentary column. It } \\
\text { has completely transparent internal structure with } \\
\text { almost no internal reflections. Its upper reflection } \\
\text { represents the seafloor and it generally has a strong } \\
\text { and distinctive bottom reflection. The thickness of } \\
\text { U1a is maximum } 20 \mathrm{~m} \text { and it includes biogenic } \\
\text { sediments/shell fragments. } \\
\text { It mainly consists of terrigenous sediments of silty } \\
\text { shale and sandy mud ( } 0-11500 \text { years). }\end{array}$ \\
\hline & & U1b & 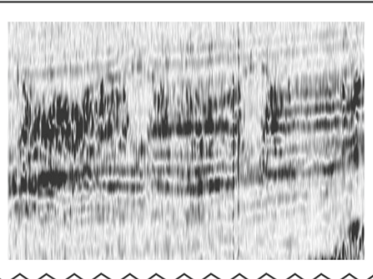 & $\begin{array}{l}\text { U1b is observed only inside and western part of the } \\
\text { outlet of Büyükçekmece Bay, and Bosphorus outlet } \\
\text { in the eastern platform. It consists of sub-parallel low } \\
\text { amplitude reflections which terminate with onlaps } \\
\text { onto U2. Its maximum thickness along the shelf is } \\
\text { approximately } 15 \mathrm{~m} \text {. } \\
\text { Lacustrine sediments of U1b consist of shale, silt and } \\
\text { coal fragments deposited after LGM (20000-11500 } \\
\text { years). }\end{array}$ \\
\hline 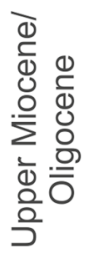 & \multicolumn{2}{|c|}{ U2 } & 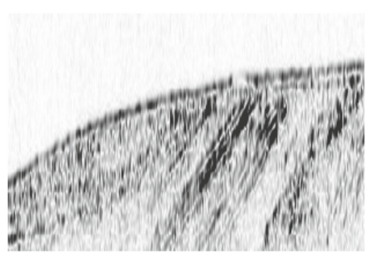 & $\begin{array}{l}\text { U2 is the acoustic basement defined as sigmoid } \\
\text { progradational and discontinous strong reflections of } \\
\text { Miocene or Oligocene age. In some areas to the } \\
\text { west, it outcrops to the seafloor, and in places, it } \\
\text { terminates at the base of U1b with toplaps. } \\
\mathrm{U} 2 \text { consists of lake or fluvial sediments for Miocene } \\
\text { unit and deltaic sediments for Oligocene unit, mainly } \\
\text { composed of shale, sandstone and siltstone with } \\
\text { some sandy limestone in Osmanclk unit. }\end{array}$ \\
\hline
\end{tabular}

Figure 4. The seismic units, sub-units and their specifications defined in the study area and their appearance on the seismic data.

seismic data interpreted as acoustic basement. Both units are separated by a distinctive unconformity surface related to the sea level fall during the forced regression at LGM, and we interpret that the base of U1 corresponds to top of Miocene or older sediments. In most of the study area, penetration of the high-resolution seismic data does not allow to define internal structure of U2 in detail.

Upper and lower boundaries of U1 represent the present-day seafloor and base of Plio-Quaternary deposits, respectively. U1 unconformably overlies U2 all over the shelf except a small area in the western platform where U2 outcrops at the seafloor. U1 is deposited depending on the morphology of the acoustic basement: It is relatively thick in the areas where U2 is eroded or within the local valleys or depressions in U2.

In general, U1a overlies U1b somewhat conformably. It is suggested that the depositional and environmental conditions during the deposition of both sub-units are slightly different all over the shelf area. U1a is a seismic unit with a homogeneous appearance on the seismic data with no or low-amplitude internal reflectivity character (figure 3). U1a is relatively thick in a narrow zone along the whole coastline as well as SW of the Bosphorus outlet, and it has maximum thickness (approximately $22 \mathrm{~m}$ ) in the Büyükçekmece Bay. Its transparent structure on the seismic data indicates that this unit is deposited under relatively low-energy conditions which produced almost no internal reflections. U1a is more or less continuous and has an undeformed character along the shelf which shows that it is not cut by faults or other structural elements such as small scale ridges. This unit includes coastal onlaps to the south, which indicate the possibility of marine transgression.

U1b constitutes the deeper parts of U1, and its base terminates on the upper surface of U2 with low angle onlaps (figure 3 ). Internal structure of U1b shows parallel to sub-parallel undeformed reflections which generally exhibit good lateral consistency on the seismic data (figure 4), which indicates that the oceanographic conditions during the accumulation of U1b were not stable and it accumulated in relatively high-energy conditions. U1b deposits in the western platform and in the Büyükçekmece Bay probably consist of fluvial sediments transported by a river which fed the Büyükçekmece Lake and reached the shelf via Büyükçekmece Bay. The same unit in the Bosphorus outlet, however, involves sandbars transported by the Bosphorus outflow and accumulated in the submarine valleys within the eastern platform.

$\mathrm{U} 2$ is acoustic basement overlaid by younger sediments of U1. It typically shows chaotic and highly inclined, parallel to sub-parallel or wavy internal reflections (figure 4). These reflections 
were possibly formed by fine-grained sedimentary rocks deposited under high-energy conditions followed by successive deformation and erosion processes. High inclinations within the U2 and the normal faults extensively observed in this unit indicate that U2 has undergone extensive deformation.

\subsection{Stacking pattern}

Distribution of Plio-Quaternary stratigraphic units is investigated within the western, central and eastern platforms separately, and thickness maps for each unit are calculated (figure 5). Figure 5(a) illustrates the thickness distribution of $\mathrm{U} 1$ (U1a+U1b). $\mathrm{U} 1$ is relatively thick in areas where the acoustic basement has depressions or valleys such as SW of Bosphorus outlet, in Büyükçekmece Bay and the narrow elongated zone between Büyükçekmece Bay and Silivri. Thickness of this unit is maximum within the Büyükçekmece Bay reaching more than $35 \mathrm{~m}$. U1a covers almost all of the study area except an elongated zone within the western platform where the acoustic basement outcrops with no recent sedimentation (figure $5 \mathrm{~b}$ ). U1b exists in only some restricted areas along the shelf: In the central part of western platform, in Büyükçekmece Bay and SW of the Bosphorus outlet in the eastern platform (figure 5c). It has a maximum thickness in the eastern platform (approximately $20 \mathrm{~m}$ ) around the sandbar. U2 is supposed to be Miocene or Oligocene sediments, and it outcrops in a narrow area in the western platform as an erosional
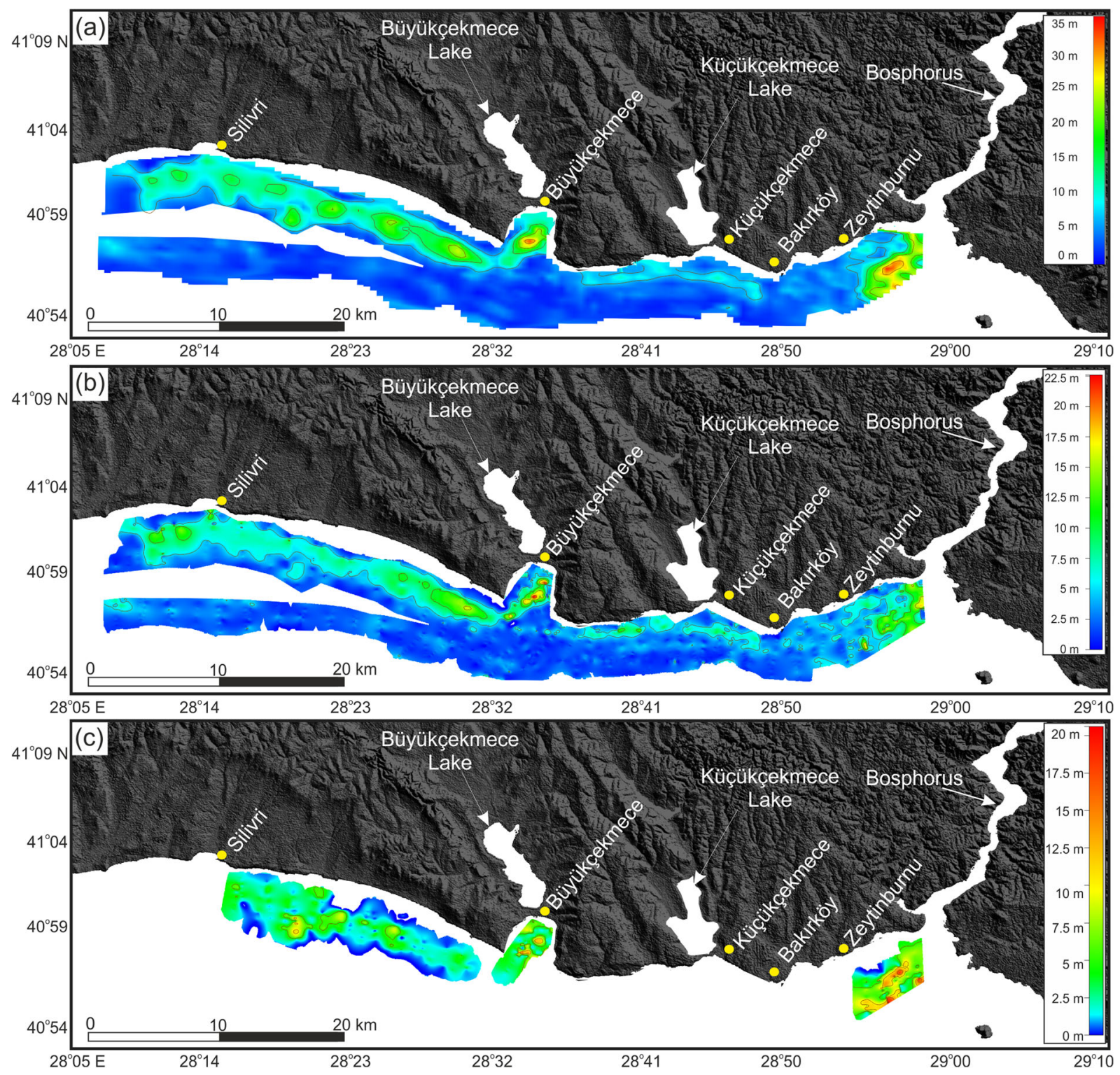

Figure 5. Thickness map of Holocene units along the northern shelf of Marmara obtained from all available high-resolution seismic data. Thickness maps of (a) U1 (U1a+U1b), (b) U1a only and (c) U1b only. 

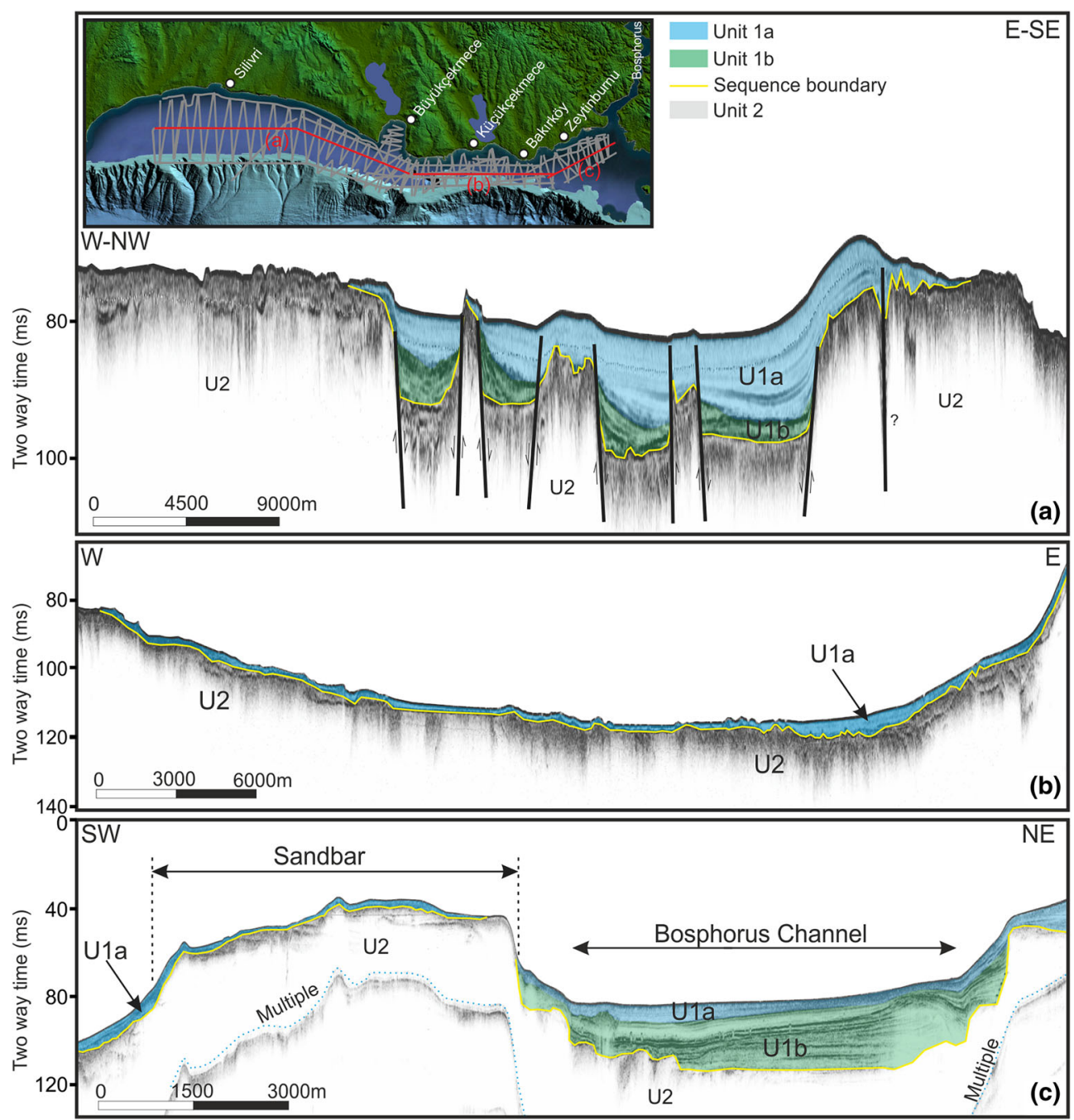

Figure 6. An example Chirp seismic line illustrating the overall Holocene stratigraphy from western to eastern part of the shelf. The data from (a) western, (b) central and (c) eastern platform. There are four distinctive depressions separated by three narrow ridges controlled by vertical faults in the western platform filled by U1a and U1b sediments, while central platform has only a thin layer of U1a sediments. Eastern platform shows a thick sequence of recent sediments filling the Bosphorus channel.

surface. Upper surface of U2 is quite irregular and constitutes an angular unconformity with the overlying sediments.

Figure 6 shows a long Chirp seismic line from western to eastern platform, which illustrates the general appearances of both U1 and U2 within the individual parts of the study area. The westernmost part of the shelf shows no Plio-Quaternary sedimentation possibly due to the strong sea floor erosion and/or non-deposition, whereas the central part of the western platform has significant deposits accumulated within the several successive depressions (figure 6a) possibly controlled by near-vertical normal faults. In this part of the shelf, top of U2 shows irregular topography indicating a strong sub-aerial erosion during the LGM.
In the central platform, however, we observe a considerably thin Plio-Quaternary sedimentation overlying U2 (figure 6b). In addition, U1b does not exist in the central platform where U1a directly overlies acoustic basement. The eastern platform exhibits a quite different stratigraphy (figure 6c). The seismic data show a thick recent sediment accumulation especially within the Bosphorus channel, at the eastern and southern part of the sandbar. While there is a thick sequence of U1a and U1b within the channel, we observe only U1a over the sandbar in some limited areas. In this part of the shelf, U1b corresponds to deltaic sediments originated from Bosphorus outflow.

In the western platform, both sub-units U1a and U1b can be observed especially within the 

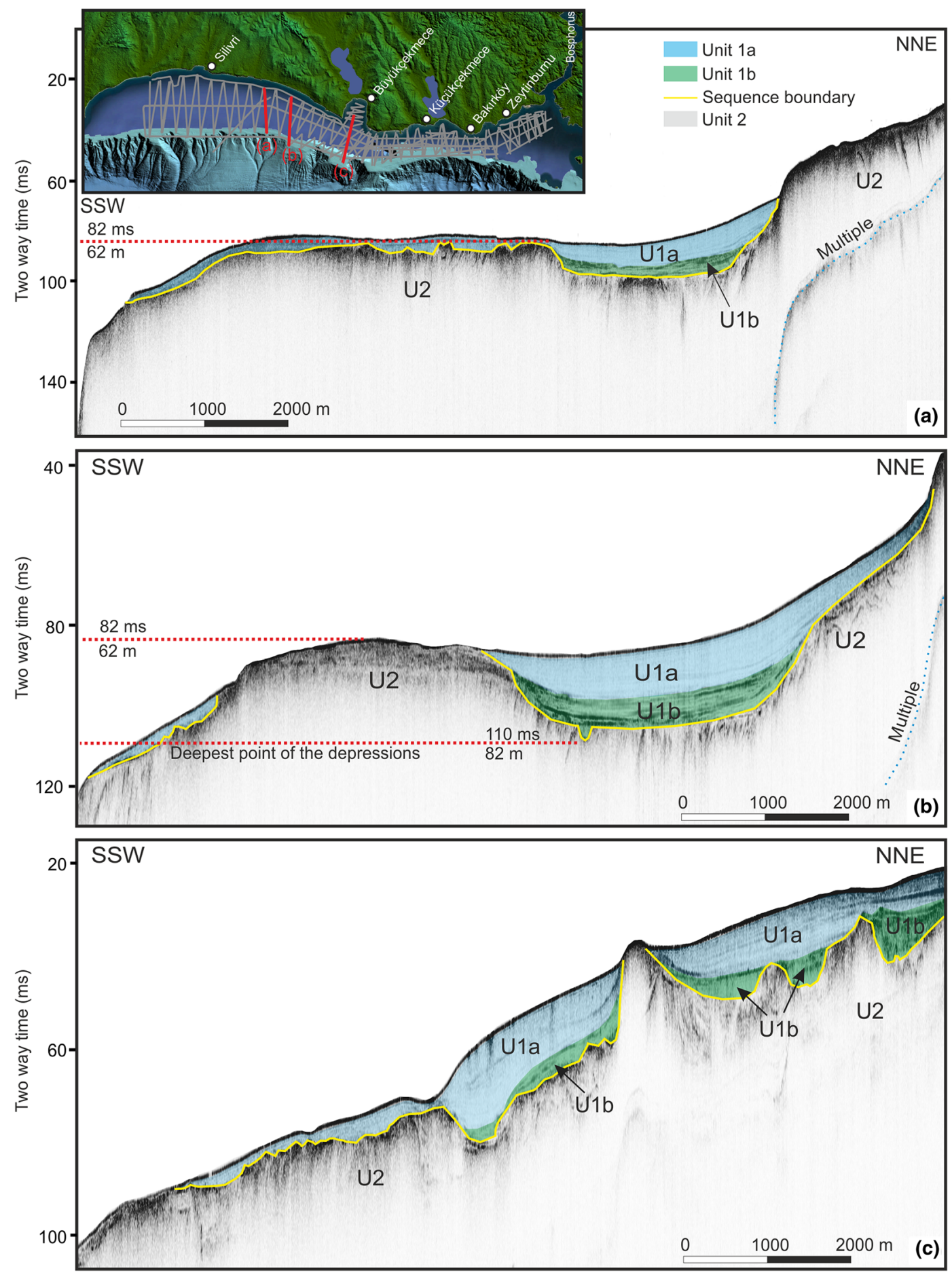

Figure 7. The high-resolution seismic sections from the western part of Büyükçekmece. This part of the shelf is characterised by a series of buried valleys filled with U1b sediments sometimes unconformably overlaid by U1a. The deepest and shallowest parts of these depressions lie at -82 and $-62 \mathrm{~m}$, respectively.

depressions along the central part of the platform. Figure 7 shows three example seismic lines from this region to demonstrate the shallow stratigraphy of the western platform. A narrow depression area at the central part is completely filled by the sediments of U1. U1b is locally observed at the base of the depressions and has a high amplitude sub-parallel reflection character. In this area, the boundary between U1a and U1b is generally concordant to the west while it shows onlap terminations towards the Büyükçekmece Bay to the east. In the western platform, we determine four 

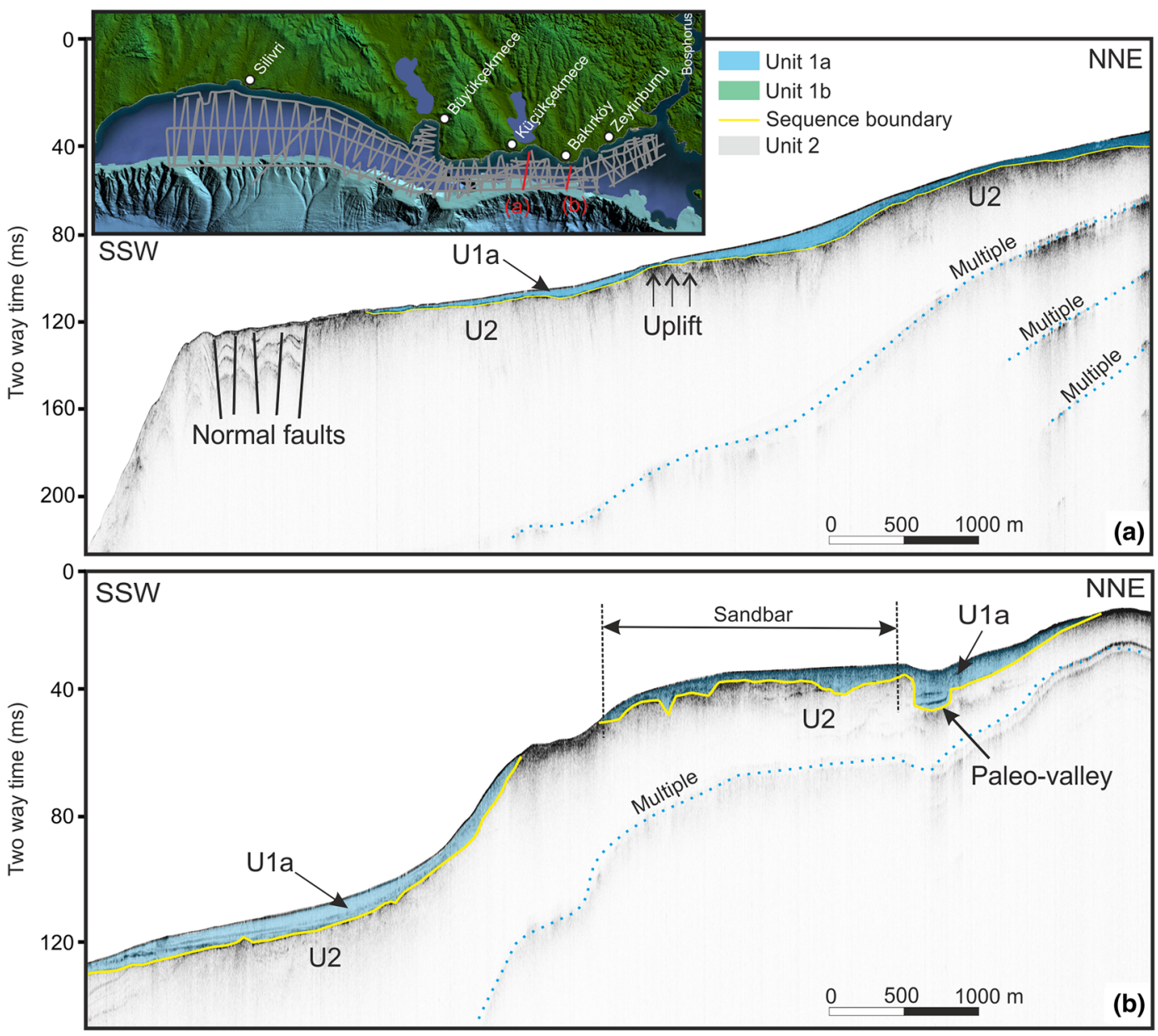

Figure 8. The high-resolution seismic sections offshore of Küçükçekmece. There is no U1b in this part of the shelf and U1a sediments directly overlie the acoustic basement U2.

depressions separated by local ridges (figures 6 a and 7). Assuming a $1500 \mathrm{~m} / \mathrm{s}$ seismic velocity for shallow sediments, the threshold depths for these depressions to their southernmost points can be determined as $-62 \mathrm{~m}$ and the deepest point of the depressions reaches $-82 \mathrm{~m}$ depth from the present-day sea level. Existence of these depressions with quite similar threshold values suggests that the western platform may have palaeolakes during the LGM when the entire shelf is exposed. The depression field in the western platform is isolated from palaeo-Marmara lake during the LGM at a $-62 \mathrm{~m}$ depth threshold (figure 7 ), and it is suggested that the sedimentation in these depressions changed from lacustrine to marine stage when the palaeo-Marmara sea level exceeded $-62 \mathrm{~m}$ threshold value during the last transgression period.

Thickness of the recent sediments in the central platform is relatively low and only U1a is observed directly over U2. Figure 8 shows two seismic sections from this part of the shelf. In the central part, seismic data indicate a small-scale uplift in U2, which possibly resulted from a local compression in this area. While the thickness of U1a is relatively higher at both northern and southern sides of the uplift, it is considerably thin at the tip of the uplift (figure 8a). U1 is maximum $14 \mathrm{~m}$ thick in the central platform (figure 5b) and onlap terminations are observed at its bottom reflection. A small-scale valley structure, which is filled with U1 sediments today, is also observed offshore of Küçükçekmece Lake towards east (figure 8b), and it is possibly the remnants of a river flowing through the lake to the eastern shelf during the last low stand. The easternmost part of this area is also characterised with a distinctive sandbar located at the Bosphorus outlet.

Deposition and sediment transport are among complicated hydrodynamic conditions in the eastern platform due to the two-way water flow system of the Bosphorus and the riverine inputs from 

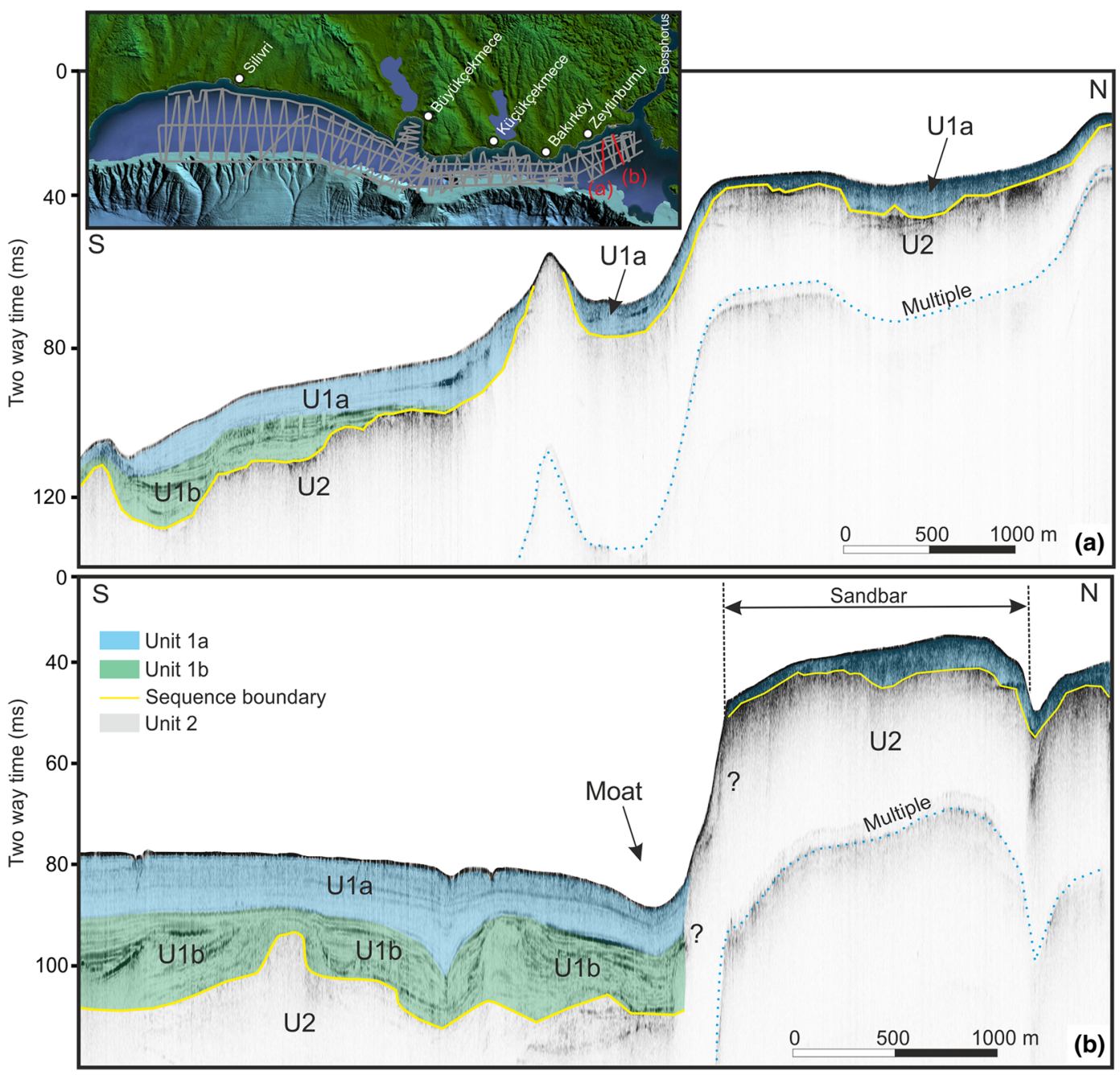

Figure 9. High-resolution seismic sections from the eastern platform, eastern part of the Küçükçekmece. A distinct sandbar to the north limits the southern distribution of the Holocene sediments.

Zeytinburnu. U1a and U1b can be observed in the eastern platform, both of which are considerably thick on the shelf as like within the Büyükçekmece Bay in the central platform, where U1a and U1b reach 15 and $17 \mathrm{~m}$ thickness, respectively. Sigmoidal reflections located just western part of the Bosphorus outlet cannot be distinguished by our seismic data in detail possibly because of the resolution limitations of the seismic signal, and therefore, they are all included in U1 (figure 9). One of the most prominent structures in the eastern platform is the sandbar, which is approximately $1500 \mathrm{~m}$ wide, located at the easternmost part of the shelf. It constitutes a small-scale mound with a height of approximately $20 \mathrm{~m}$ from the seafloor and is a transparent internal structure on the seismic data. It also does not allow the signal penetration; hence its internal structure cannot be solved by the high-resolution seismic dataset.

\section{Discussion}

Northern Marmara shelf is morphologically more or less uniform when compared to the southern shelf. The bathymetry between Silivri and Küçükçekmece indicates an almost flat morphology reaching the continental slope at approximately $90 \mathrm{~m}$ water depths to the south with a relatively low bathymetric gradient (figure 2). Tur et al. (2015) suggest several lineaments obtained from their multibeam bathymetric data, which cut the regular shelf morphology around the Bosphorus and Küçükçekmece lagoon. In addition, two distinctive canyons offshore Büyükçekmece Bay indicate that there is a significant amount of sediment transport in this area along the slope.

The shelf is characterised by thin PlioceneQuaternary deposits overlying Miocene and Oligocene units. Recent sediments accumulated on 
an erosional surface formed during the last low stand affected the entire shelf area. Towards the shelf break, the older units are truncated by the heads of large canyons and several near vertical normal faults.

According to the seismic data, shelves of the Marmara Sea became exposed, and the lake level of Marmara remained at the sill depth of Dardanelles during the LGM (Aksu et al. 1999; Eriş et al. 2007, 2011; Çağatay et al. 2009). Connection between Marmara and Mediterranean was established following the inter-glacial period which is related to a rapid sea level rise $(12,000$ yr BP). During this transgression period, a number of marine terraces were developed along the northern shelf. Karakılçık et al. (2014) indicate the existence of four submarine terraces on the seismic data lying at approximately $-65,-87,-93$, and $-102 \mathrm{~m}$ water depths offshore Büyükçekmece. Eriş et al. (2011) suggest that the terrace at $-85 \mathrm{~m}$ water depth refers to a stable sea level period after Holocene sea connection was established. They also indicate that fresh water transgression stage of the Marmara Lake was formed 15,000-13,500 yr BP, and, according to the wave-cut terraces on the northern shelf, it increased the sea level to $-85 \mathrm{~m}$ approximately 13,000 yr BP. A stable sea level at $-65 \mathrm{~m}$ water depth occurred following the Younger Dryas (YD) possibly 10,100 yr BP which resulted in the most distinctive erosional terrace and palaeoshoreline in the northern shelf (Çăgatay et al. 2003). Although they are not continuously observed all over the shelf, and are quite distinctive in the areas of west and east of the Büyükçekmece Bay in the central platform, high-resolution seismic data interpreted in this study indicate that there are two more shallow water terraces located at -24 and $-13.5 \mathrm{~m}$ water depths (figure $3 \mathrm{~b}$ ). These terraces also suggest that the relative sea level rise in the Marmara Sea was interrupted several times during the last stages of the transgression period.

Environmental conditions for sediment accumulation on the northern Marmara shelf have been investigated by several researchers in the last two decades using core data as well as seismic datasets with different resolution and distributions along the shelf (Hiscott et al. 2002; Gökaşan et al. 2005; Eriş et al. 2007, 2011; McHugh et al. 2008; Çağatay et al. 2009; Karakılçık et al. 2014; Tur et al. 2015; Aksu et al. 2016; Köprülü et al. 2016). Although the naming of the units they discriminate from their seismic data is different for each study, they typically indicate three different units from seafloor to deeper sediments for Plio-Quaternary stratigraphy: A topmost sedimentary cover, basinwards prograding deltaic sediments and generally parallel to sub-parallel marine sediments. Bottom surface of recent sediments represents a regional unconformity surface formed during the last lowstand in Marmara Sea. $\mathrm{C}^{14}$ analyses show that this surface is formed 12,000 yr BP (Hiscott and Aksu 2002; Eriş et al. 2007, 2011; Çăgatay et al. 2009). In this study, two stratigraphic units are discriminated by analysing the seismic data, which are indicated as U1 and U2. The boundary between the two is interpreted as a regional unconformity surface for the entire northern shelf, and is formed during the sub-aerial erosion within the last lowstand period between MIS2 and MIS3.

$\mathrm{U} 1$ is defined as the youngest sediment accumulation on the shelf, and is interpreted as the post-Miocene/Oligocene sediments (Çăgatay et al. 2003; Eriş et al. 2007). According to Eriş et al. (2011), marine regression and a subsequent seafloor erosion occurred along the northern shelf due to the climatological effects and river erosion when the lake level was stable at approximately $-90 \mathrm{~m}$ during the LGM covering whole MIS2 period. Although we do not have core information for dating, it is hereby concluded that the base of U1a corresponds to this surface based on the careful examination and comparison of the seismic data with the previous studies. The same horizon was also distinguished by Aksu et al. (2016) on their seismic data and they named it as $\beta 2$ reflector which is termed elevation of Bosphorus delta front in the eastern platform. They give the age of $\beta 2$ reflector as $11.8 \pm 0.3$ (cal ka).

U1 is interpreted as the Plio-Quaternary succession and sub-divided into two parts as U1a and U1b. When compared to the results of Köprülü et al. (2016) from the Bosphorus outlet, U1a corresponds to $\mathrm{U} 1$ and $\mathrm{U} 2$, and $\mathrm{U} 1 \mathrm{~b}$ corresponds to Unit 3. Karakılçık et al. (2014) named U1 as SU IV and did not separate it into two sub-units. U1a constitutes the most recent sedimentary unit deposited during the Holocene following the LGM and overlies U1b, where it exists, or U2 unconformably with onlap terminations. Coastal onlaps within the southern part of U1a suggest that this unit was deposited during the transgression period. The high-resolution seismic data used in this study suggest that U1b is primarily an infill unit filling in the depressions or submarine valleys, which typically exists within the western platform and the Bosphorus outlet, and is interpreted as Pliocene 
lacustrine sediments. Furthermore, U1b exists only in areas shallower than $-62 \mathrm{~m}$ water depths. Therefore, we conclude that the interface between U1a and U1b corresponds to top of lacustrine sediments formed during the last low stand. Although there are some biogenic sediments formed by shell fragments on the shelf, the sediments of U1b are generally terrigenous (Karakılçık et al. 2014).

$\mathrm{U} 2$ generally terminates at the base of U1 forming angular unconformities and is interpreted as acoustic basement. It corresponds to acoustic basement defined by Köprülü et al. (2016) and SU I, SU II and SU III for the data interpreted by Karakılçık et al. (2014). U2 consists of highly inclined, wavy, sub-parallel and sometimes chaotic internal reflections. We suggest that the chaotic structure is the result of either fine-grained sediments deposited under high-energy conditions or local deformation occurred after deposition. This unit is widely affected by the northern branch of the NAF or local faulting such as Çatalca fault (Ergintav et al. 2011) and erosional processes. It shallows in the western platform and outcrops in some specific places in the west.

Upper surface of the acoustic basement is irregular related to the sub-aerial erosional processes which occurred during the LGM and produces a distinctive high amplitude reflection on the seismic data. Although the age of U2 is controversial, it is proposed that it consists of Oligoceneupper Miocene sediments (Ergintav et al. 2011; Karakılçık et al. 2014; Tur et al. 2015). Tur et al. (2015) proposed that U2 is inferred to be the seaward continuation of the Oligocene-upper Miocene units widely exposed on land. According to Karakılçık et al. (2014), U2 represents Oligocene sediments in the west between Silivri and Büyükçekmece, while it corresponds to Miocene sediments in the east between Büyükçekmece and Zeytinburnu.

Upper Oligocene sediments are named as Osmancik Formation in the northern shelf, which is formed by sub-parallel reflections with good trace-by-trace consistency. Beyond the shelf break, the sediments of this unit deepen to the south with significantly high inclinations. This situation is also evident in high-resolution data (figures $3 \mathrm{c}$ and $7 \mathrm{~b}$ ). Osmancik Formation creates two large anticline structures in the western platform (Nasif 2016), and the multichannel seismic data indicate that the tips of both anticlines are truncated during the last low-stand outcropping the seafloor, which enables Plio-Quaternary sediments accumulate directly over the Oligocene age Osmancık Formation. Nasıf (2016) suggests that this formation is truncated at the seafloor during the LGM in most parts of the western platform, between Büyükçekmece Bay and Küçükçekmece in the central platform and in the easternmost part of the shelf close to the Bosphorus outlet.

In most parts of the shelf, Holocene sediments directly overlie the Oligocene acoustic basement. Since the riverine inputs are quite restricted in the northern shelf, Holocene sediment thickness is relatively low for the entire shelf except the area of Bosphorus outlet and Büyükçekmece Bay (figure 5). We observe relatively thick accumulations in the SW of Bosphorus outlet, inside of the Büyükçekmece Bay and in the western platform along the coastal area between Silivri and Büyükçekmece Bay. Total Holocene sediment thickness reaches $36 \mathrm{~m}$ around the Bosphorus outlet and Büyükçekmece Bay while it is maximum $25 \mathrm{~m}$ in the western platform. Using their highresolution seismic data, Vardar et al. (2018) also reported similar thickness values for Büyükçekmece Bay. In general, thickness increases towards the land area to the north along the entire shelf, which indicates that the recent sedimentation is fed from land via riverine inputs into the shelf. Thick postglacial sedimentation near the Bosphorus outlet includes deltaic sediments in places, and is interpreted as the sediments transported via Bosphorus outflow as suggested by several authors (Karakılçık et al. 2014; Tur et al. 2015; Aksu et al. 2016; Köprülü et al. 2016).

Tur et al. (2015) prepared the Plio-Quaternary basin fill map of the northern Marmara shelf between Büyükçekmece Bay and Bosphorus strait illustrating the post-Miocene sediment distribution considering the acoustic basement as Miocene sediments. However, when we compare the deeper stratigraphy obtained from multichannel seismic data with the stratigraphy information from K. Marmara-1 well located at the NW part of the study area, we observe that the area is almost lacking the Miocene sediments, and the PlioQuaternary basin fill directly overlies mostly Osmancık, and in some places Mezardere, units of Oligocene age. Plio-Quaternary sediment thickness map of this study (figure 5a) is quite similar to post-Miocene thickness map suggested by Tur et al. (2015).

A similar thickness map of Holocene sediments for the northern shelf is suggested by Karakılçık et al. (2014), in which the thickness of the Holocene 
sediments exhibits a more regular distribution along the western platform whereas it shows a variable distribution for the eastern platform close to the Bosphorus outlet. Although they did not discriminate the areas where the Holocene sedimentation does not exist, their thickness map is similar to that obtained in this study (figure 5b) except that they suggest a thicker Holocene sediment distribution in the eastern platform. They also suggest that the average sedimentation rate on the shelf and deep basin are 0.4 and $1.2 \mathrm{~m} / 1000 \mathrm{yr}$. Based on the Holocene sediment thickness obtained from our seismic data, we calculated the average sedimentation rate for western, central and eastern platforms as $0.4,0.3$ and $0.5 \mathrm{~m} / 1000 \mathrm{yr}$ for last $12,000 \mathrm{yr}$, which indicates an average sedimentation rate for overall northern shelf as $0.4 \mathrm{~m} / 1000$ yr. Çağatay et al. (2003), however, suggested a much lower value of $0.1 \mathrm{~m} / 1000 \mathrm{yr}$ for the northern shelf, which is quite low when compared to the southern shelf which is fed by several rivers.

Palaeo-bathymetric maps of the shelf indicate that there were a number of submarine valleys and depressions formed during the LGM especially around the Bosphorus outlet and western part of the Büyükçekmece Bay (figure 5a). We suggest that these depressions in the western platform may correspond to palaeolakes which were fed by riverine inputs during the last low-stand period when the Marmara was an enclosed lake. Four WNW-ESE trending lakes are located between Büyükçekmece Bay and Silivri, and are aligned to the coastline separated by narrow ridges. These valleys are also defined by Karakılçık et al. (2014) who suggested that they are depressions filled with relatively thick Holocene sediments.

Seismic data show that the palaeolakes on the shelf are bordered with $-62 \mathrm{~m}$ depth contour during the LGM on the western platform, the borders of which (i.e., $-62 \mathrm{~m}$ depth contour) are shown in figure 10. The base of the lakes are filled with U1b sediments which consist of shale, silt and coal fragments while marine sediments involve silty shale and sandy mud (Karakılçık et al. 2014).

Today, there are a number of moderate-size creeks, such as Karasu, Delice, Tepecik, Koğuk and Karasu rivers, flowing into the northern shelf via Büyükçekmece Bay. We tentatively suggest that this river system running towards the west along the coastline flowing through Büyükçekmece Lake and Bay could feed these lakes when the relative sea level was at its minimum state (figure 10). The morphology of the southern exit of the Büyükçekmece Bay is quite suitable for such a river flow where, along with the outlet of Küçükçekmece Lake, seismic data indicate small palaeovalleys and river erosion. Sand deposits exist at the SW side of the lakes, which indicate that they are accumulated by coastal currents. A similar valley structure is also observed offshore Zeytinburnu, which deepens towards the Küçükçekmece Lake offshore. The northern part of the sandbar located offshore Yenikapı indicates the clues of river erosion, which is also defined by Köprülü et al. (2016) who also suggested this structure deepens towards the Bosphorus canyon to the east.

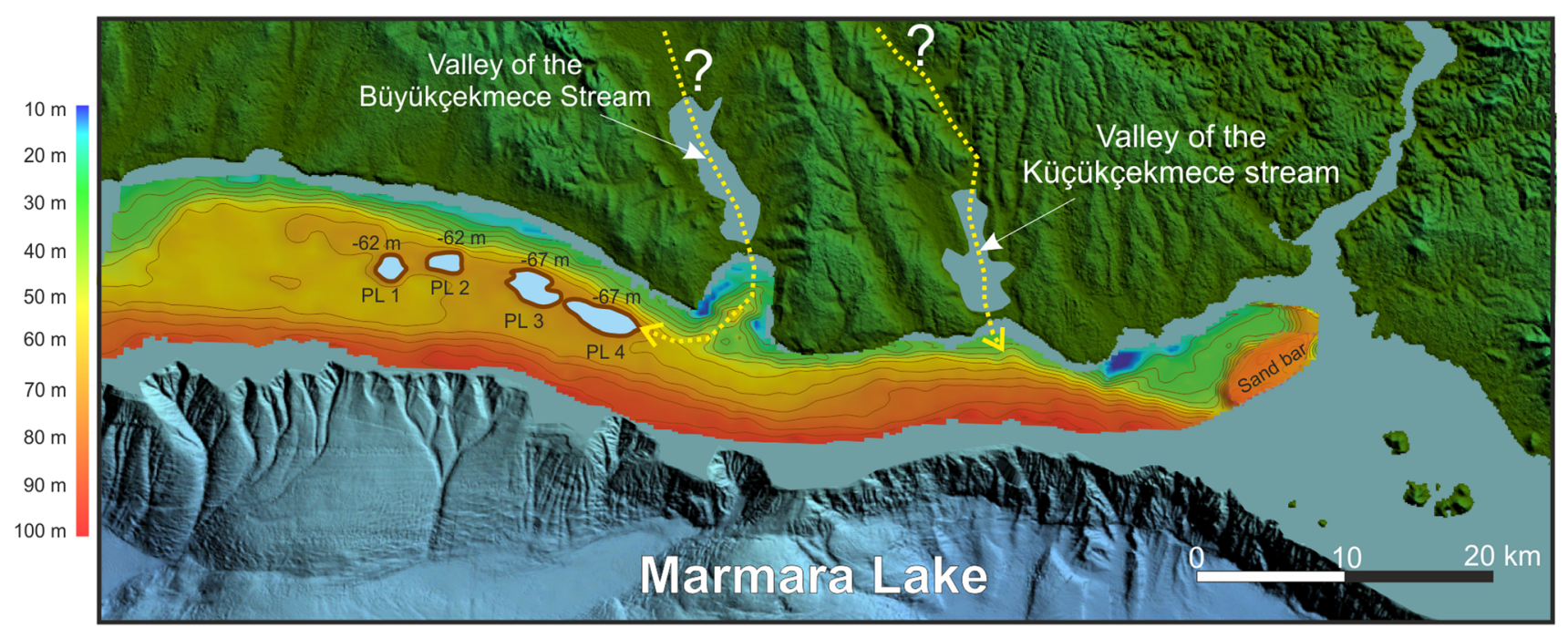

Figure 10. Northern shelf during the LGM. PLs represent palaeolakes. Yellow dashed lines indicate the possible rivers flowing into the shelf. Basal depths of the palaeolakes are also indicated. 
Figure 11 shows a multichannel seismic line cross-cutting the palaeolakes illustrating the deeper structure and stratigraphy of the western platform. The palaeolakes are also distinctive structures on the multichannel seismic line, and the base of the lakes is determined by a marked reflection from an erosional surface. Seismic data also indicate that the sediments of U2 are strongly deformed, and inclined in the central part. We also observe several near-vertical normal faults with small slip rates, which reach the base of the palaeolakes deforming the base of U1. Ergintav et al. (2011) mapped these faults as the offshore continuation of rightlateral Çatalca fault. Gökaşan et al. (2002) and then Tur et al. (2015) suggest the existence of a WNW-ESE trending right-lateral active fault on the shelf based on the interpretations using the lineaments on the land topography and offshore bathymetry. The existence of deeper faults on the multichannel seismic data also indicates that the formation mechanism of these palaeolakes may also be controlled by local tectonic setting of the northern Marmara shelf.

Figure 12 shows the conceptual model for the formation of palaeolakes. Depressions along the western platform were fresh water lakes when the sea level of Marmara was at its low stand state of approximately $-90 \mathrm{~m}$ at the end of LGM. U1b was deposited within the lakes and sub-aerial erosion occurred where the shelf was exposed at this stage (figure 12a). During the rapid transgression period following the LGM, U1b was deposited in areas close to the shelf break (figure 12b). A relatively thick sediment of U1b was deposited over U1a within the palaeolakes and over the shelf area when the sea level exceeded $-62 \mathrm{~m}$ threshold depth, which also resulted in transition from lacustrine to marine environments of the palaeolakes (figure 12c). Lambeck et al. (2007) predicted relative sea level changes for the last 20,000 yr for
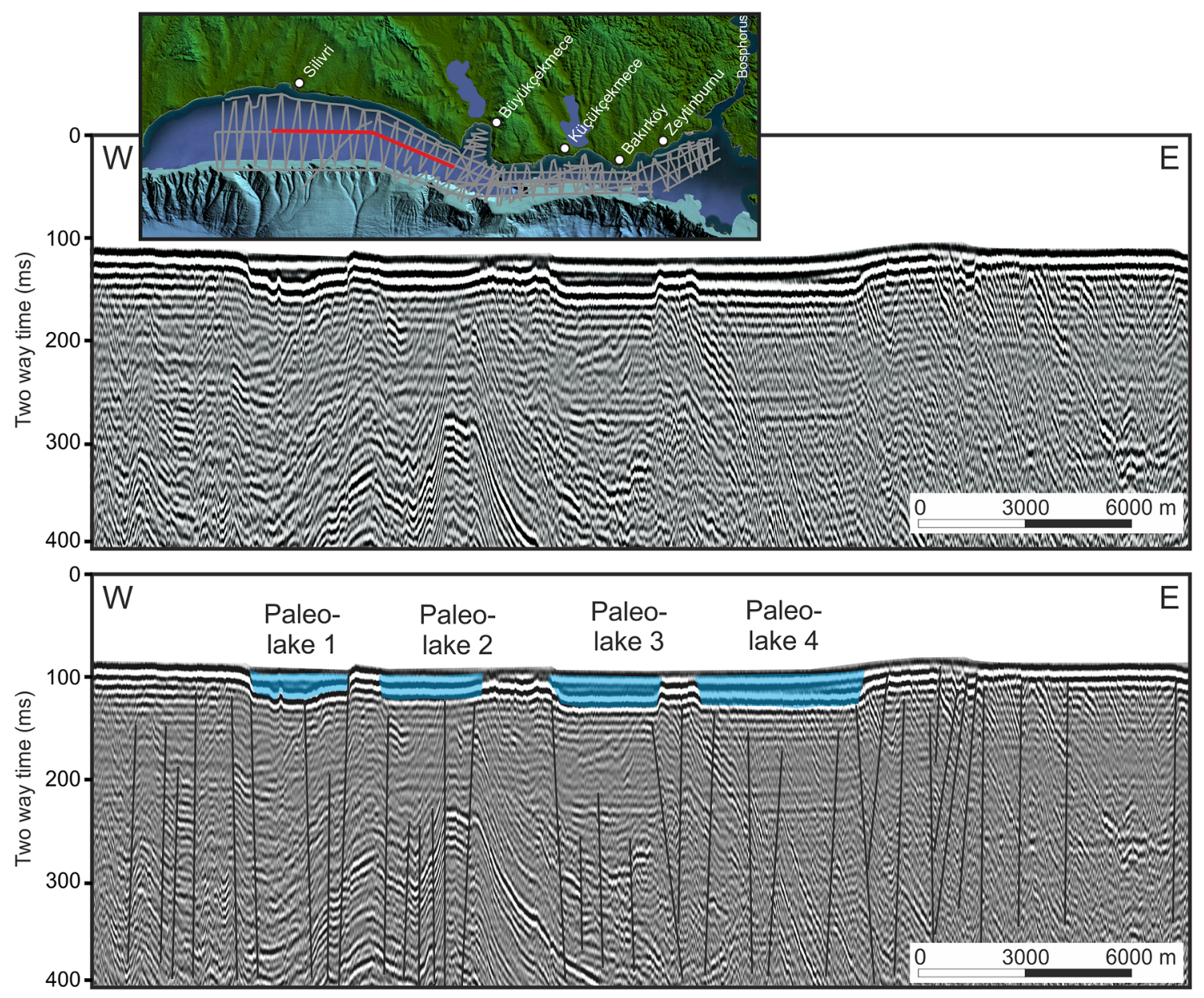

Figure 11. Uninterpreted (top) and interpreted (bottom) multichannel seismic line between Silivri and Büyükçekmece Bay. The seismic data indicate that the deeper sediments of the northern shelf are deformed by several near vertical normal faults. Palaeolakes are shown by blue shaded zones which are structurally controlled by normal fault system beneath the lakes. 

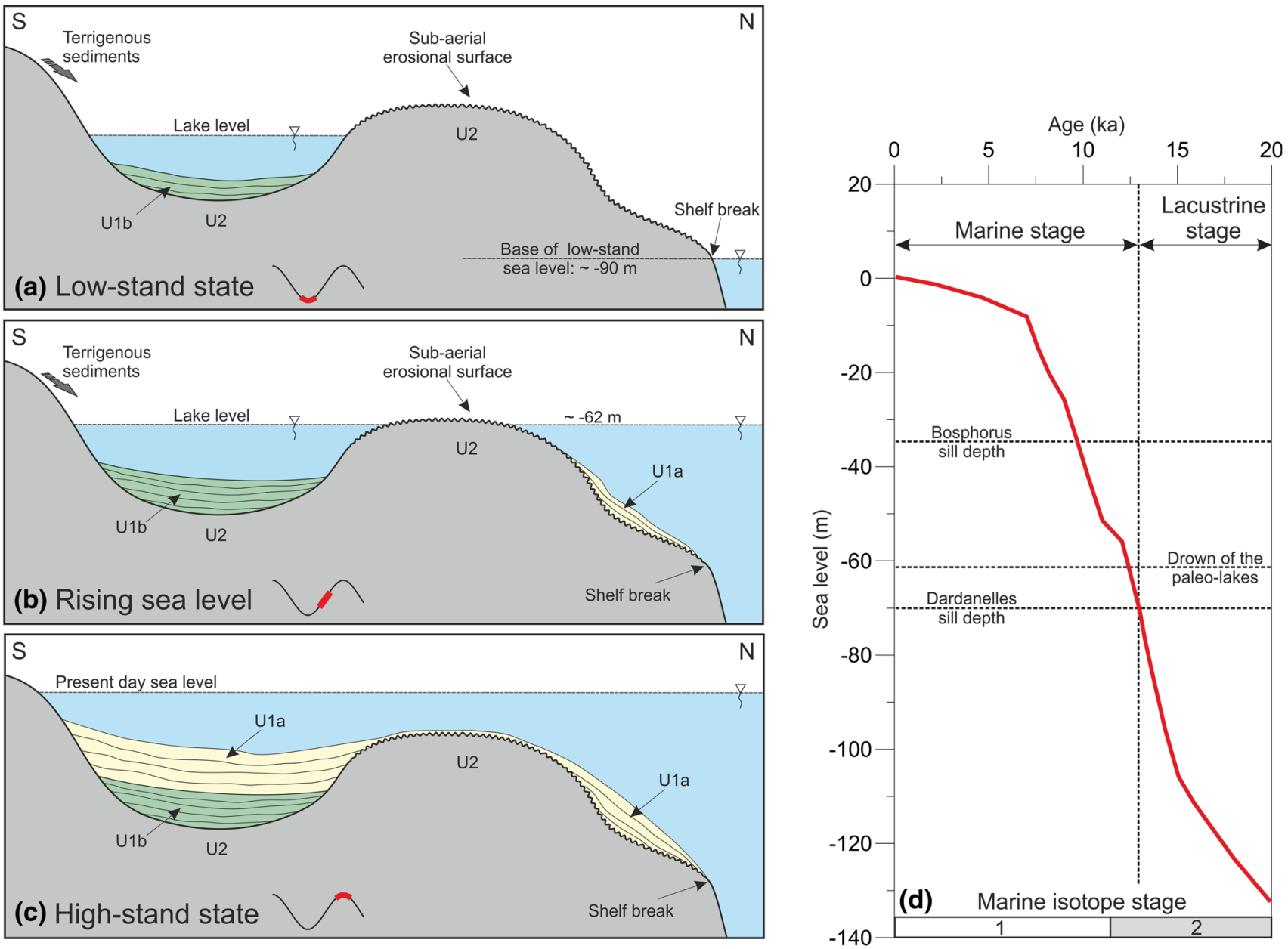

Figure 12. Conceptual model for the formation of palaeolakes (vertical scale is arbitrary). (a) At the end of LGM, relative sea level of Marmara was approximately $-90 \mathrm{~m}$ and the depressions in the western platform were fresh water lakes where U1b was deposited. (b) During the rapid transgression period, U1b was deposited close to the shelf break. (c) When the sea level exceeded $-62 \mathrm{~m}$ threshold depth, U1b was deposited over U1a within the palaeolakes and over the shelf. (d) Predicted sea level variations at Bosphorus sill for last 20,000 yr for Marmara Sea (from Lambeck et al. 2007). The transition from lacustrine to marine conditions of the palaeolakes at approximately 12,000-12,500 yr BP is also indicated.

Marmara Sea considering the present-day sill depths of Dardanelles and Bosphorus straits (figure 12d). Assuming no tectonic uplift and/or subsidence, we propose that this transition of the palaeolakes from lacustrine to marine conditions occurred at approximately 12,000-12,500 yr BP.

\section{Conclusions}

Seismic data indicate that the northern Marmara shelf is an elongated platform highly affected by forced regression and rapid transgression as well as sub-aerial erosion processes during and after the LGM. Based on the interpretation of highresolution seismic data, two stratigraphic units (U1 and U2) are discriminated along the shelf, separated by a regional unconformity surface observed along the entire northern shelf, formed by the sub-aerial erosion during the last low stand. While U2 represents the acoustic basement corresponding to the upper Miocene or Oligocene sediments, U1 is interpreted as the Plio-Quaternary deposits sub-divided into two parts as U1a and U1b.

$\mathrm{U} 1 \mathrm{~b}$ is a unit filling in the localised depressions or submarine valleys located within the western platform and the Bosphorus outlet in areas shallower than $-62 \mathrm{~m}$ water depths, and is interpreted as Pliocene lacustrine sediments, indicating that the top of U1b corresponds to top of lacustrine sediments formed during the last low stand. Coastal onlaps observed in the southern part of U1b suggest that this unit was deposited over U1a during the transgression period following the LGM. The calculated sedimentation rate for Holocene deposits 
based on the thickness distribution of Holocene sediments all over the shelf is $0.4 \mathrm{~m} / 1000 \mathrm{yr}$.

Palaeobathymetric maps obtained from highresolution seismic data indicate a number of submarine valleys and depressions formed during the LGM especially around western part of the Büyükçekmece Bay. We conclude that these depressions represent palaeolakes separated by narrow ridges, filled by lacustrine sediments of U1b during the last low-stand period when the Marmara was an enclosed lake. Transition from lacustrine to marine environments within these palaeolakes occurred when the sea level exceeded $-62 \mathrm{~m}$ threshold depth during the transgression period.

\section{Acknowledgements}

We thank the TUBITAK Marmara Research Center for their permit to use the dataset. We also thank the research team in Seismic Laboratory of Institute of Marine Sciences and Technology at Dokuz Eylül University (DEU) for their effort during the data acquisition. We are grateful to the captains and crew of $\mathrm{R} / \mathrm{V} \mathrm{K}$. Piri Reis for their professional and effective assistance. We also thank Prof Semih Ergintav for his valuable contribution and permission for using the dataset.

\section{References}

Aksu A E, Hiscott R N and Yaşar D 1999 Oscillating Quaternary water levels of the Marmara Sea and vigorous out-flow into the Aegean Sea from the Marmara Sea-Black Sea drainage corridor; Mar. Geol. 153 275-302.

Aksu A E, Calon T J and Hiscott R N 2000 Anatomy of the North Anatolian fault zone in the Marmara Sea, Western Turkey: Extensional basins above a continental transform; GSA Today 10 3-7.

Aksu A E, Hiscott R N, Mudie P J, Rochon A, Kaminski M A, Abrojano T and Yaşar D 2002a Persistent Holocene outflow from the Black Sea to the Eastern Mediterranean contradicts Noah's flood hypothesis; GSA Today 12 4-10.

Aksu A E, Hiscott R N, Kaminski M A, Mudie P J, Gillespie H, Abrojano T and Yaşar D 2002b Last glacial-Holocene paleoceanography of the Black Sea and Marmara Sea: Stable isotopic, foraminiferal and coccolith evidence; Mar. Geol. 190 119-149.

Aksu A E, Hiscott R N and Yaltırak C 2016 Early Holocene age and provenance of a mid-shelf delta lobe south of the strait of Bosphorus, Turkey, and its link to vigorous Black Sea outflow; Mar. Geol. 380 113-137.

Algan O, Çă̆atay M N, Tchepalyga A, Ongan D, Eastoe C and Gökaşan E 2001 Stratigraphy of the sediment infill in Bosphorus Strait: Water exchange between the Black and Mediterranean Seas during the last glacial-Holocene; Geo-Mar. Lett. 20 209-218.

Barka A 2002 The 17 August 1999 Izmit earthquake; Science 285 1858-1859.

Barka A and Kadinsky-Cade K 1988 Strike-slip fault geometry in Turkey and its influence on earthquake activity; Tectonics 7 663-684.

Çăgatay M N, Algan O, Sakınç M, Eastoe C, Egesel L, Balkıs N, Ongan D and Caner H 1999 A late Holocene sapropelic sediment unit from the southern Marmara shelf and its palaeoceanographic significance; Quat. Geol. Rev. 18 531-540.

Çă̆atay M N, Görür N, Algan O, Eastoe C, Tchapalyga A, Ongan D, Kuhn T and Kuşçu I 2000 Late Glacial-Holocene palaeoceanography of the sea of Marmara: Timing of connections with the Mediterranean and the Black Seas; Mar. Geol. 167 191-206.

Çağatay M N, Görür N, Polonia A, Demirbağ E, Sakınç M, Cormier M H, Capotondi L, McHugh C, Emre Ö and Eriş K K 2003 Sea-level changes and depositional environments in the İzmit Gulf, eastern Marmara Sea, during the late glacial-Holocene period; Mar. Geol. 202 159-173.

Çă̆atay M N, Eriş K, Ryan W B F, Sancar Ü, Polonia A, Akçer S, Biltekin D, Gasperini L, Görür N, Lericolais G and Bard E 2009 Late Pleistocene-Holocene evolution of the northern shelf of the sea of Marmara; Mar. Geol. 265 $87-100$.

Ergin M, Bodur M N and Ediger V 1991 Distribution of surficial shelf sediments in the northeastern and southwestern parts of the sea of Marmara: Strait and canyon regimes; Mar. Geol. 96 313-340.

Ergintav S, Demirbağ E, Ediger V, Saatçılar R, İnan S, Cankurtaranlar A, Dikbaş A and Baş M 2011 Structural framework of onshore and offshore Avcllar, İstanbul under the influence of the North Anatolian fault; Geophys. J. Int. $18593-105$.

Eriş K K, Ryan W B F, Çăgatay M N, Sancar U, Lericolais G, Menot G and Bard E 2007 The timing and evolution of the post-glacial transgression across the sea of Marmara shelf south of İstanbul; Mar. Geol. 243 57-76.

Eriş K K, Çağatay M N, Akçer S, Gasperini L and Mart Y 2011 Late glacial to holocene sea-level changes in the sea of Marmara: New evidence from high-resolution seismics and core studies; Geo-Mar. Lett. 31 1-18.

Gökaşan E, Gazioğlu C, Alpar B, Yücel Z Y, Ersoy Ş, Gündoğdu O, Yaltırak C and Tok B 2002 Evidence of NW extension of the north Anatolian fault zone in the Marmara Sea: A new interpretation of the Marmara Sea (İzmit) earthquake on 17 August 1999; Geo-Mar. Lett. 21 183-199.

Gökaşan E, Tur H, Ecevitoğlu B, Görüm T, Türker A, Tok B, Çăglak F, Birkan H and Şimşek M 2005 Evidence and implications of massive erosion along the Strait of İstanbul (Bosphorus); Geo-Mar. Lett. 25 324-342.

Görür N and Okay A I 1996 Fore-arc origin of the Thrace basin, northwest Turkey; Geologische Rundschau 85 662-668.

Görür N, Çăgatay M N, Sakınç M, Sümengen M, Şentürk K, Yaltırak C and Tchapalyga A 1997 Origin of the sea of Marmara as deduced from Neogene to Quaternary paleogeographic evolution of its frame; Int. Geol. Rev. 39 342-352. 
Görür N, Çağatay M N, Emre Ö, Alpar B, Sakınç M, İslamoğlu Y, Algan O, Erkal T, Keçer M, Akkök R and Karlık G 2001 Is the abrupt drowning of the Black Sea shelf at 7150 yr BP a myth?; Mar. Geol. 176 65-73.

Hiscott R N and Aksu A E 2002 Late quaternary history of the Marmara Sea and Black Sea from high-resolution seismic and gravity-core studies; Mar. Geol. 190 261-282.

Hiscott R N, Aksu A E, Yaşar D, Kaminski M A, Mudie P J, Kostylev V E, MacDonald J C, İşler F I and Lord A R 2002 Deltas south of the Bosphorus Strait record persistent Black Sea outflow to the Marmara Sea since 10 ka; Mar. Geol. 190 95-118.

Hiscott R N, Aksu A E, Mudie P J, Kaminski M A, Abrajano T, Yaşar D and Rochon A 2007a The Marmara Sea gateway since 16 ky BP: Non-catastrophic causes of paleoceanographic events in the Black Sea at 8.4 and $7.15 \mathrm{ky}$ BP; In: The black sea flood question: Changes in coastline, climate and human settlement (eds) YankoHombach V, Gilbert A S and Dolukhanov P M, Springer, The Netherlands, pp. 89-117.

Hiscott R N, Aksu A E, Mudie P J, Marret F, Abrajano T, Kaminski M A, Evans J C, Çakıroğlu A I and Yaşar D 2007b A gradual drowning of the southwestern Black Sea shelf: Evidence for a progressive rather than abrupt Holocene reconnection with the eastern Mediterranean Sea through the Marmara Sea Gateway; Quatern. Int. 167 19-34.

İmren C, Le Pichon X, Rangin C, Demirbag E, Ecevitoğlu B and Görür N 2001 The North Anatolian Fault within the Sea of Marmara: A new evaluation based on multichannel seismic and multi-beam data; Earth Planet. Sci. Lett. 186 $143-158$.

Kaminski M A, Aksu A E, Box M, Hiscott R N, Filipescu S and Al-Salameen M 2002 Late glacial to Holocene benthic foraminifera in the Marmara Sea: Implications for Black Sea-Mediterranean Sea connections following the last deglaciation; Mar. Geol. 190 165-202.

Karakılçık H, Ünlügenç U C and Okyar M 2014 Late Glacial-Holocene shelf evolution of the Sea of Marmara west of Istanbul; J. Afr. Earth Sci. 100 365-378.

Köprülü K, Alpar B and Vardar D 2016 Last GlacialHolocene stratigraphic development at the Marmara Sea exit of the Bosphorus Strait, Turkey; Mar. Geophys. Res. 37 21-35.

Lambeck K, Sivan D and Purcell A 2007 Timing of the last Mediterranean Sea-Black Sea connection from isostatic models and regional sea-level data; In: The black sea flood question: Changes in coastline, climate and human settlement (eds) Yanko-Hombach V, Gilbert A S, Panin N and Dolukhanov P M, Springer, The Netherlands, pp. 797808.

Major C, Ryan W B F, Lericolais G and Hajdas I 2002 Constraints on Black Sea outflow to the Sea of Marmara during the last glacial-interglacial transition; Mar. Geol. 190 19-34.

McHugh C M G, Gurung D, Giosan L, Ryan W B F, Mart Y, Sancar U, Burckle L and Çăgatay N 2008 The last reconnection of the Marmara Sea (Turkey) to the World Ocean; a paleoceanographic and paleoclimatic perspective; Mar. Geol. 255 64-82.
Mudie P J, Rochon A, Aksu A E and Gillespie H 2004 Late glacial, Holocene and modern dinoflagellate cyst assemblages in the Aegean-Marmara-Black Sea corridor; Rev. Palaeobot. Palynol. 256 1-26.

Nasif A 2016 Investigation of Northern Shelf of the Marmara Sea using seismic and acoustic data sets; MSc Thesis, Dokuz Eylül University, The Graduate School of Natural and Applied Sciences, Izmir.

Okay N and Ergün B 2005 Source of the basinal sediments in the Marmara Sea investigated using heavy minerals in the modern beach sands; Mar. Geol. 216 $1-15$.

Okay A I and Tansel İ 1994 New data on the upper age of the Intra-Pontide ocean from north of Şarköy (Thrace); Bull. Miner. Res. Explor. Turkey 114 23-26.

Okay A I, Kaşlılar-Özcan A, İmren C, Boztepe-Güney A, Demirbağ E and Kuşçu İ 2000 Active faults and evolving strike-slip basins in the Marmara Sea, northwest Turkey: A multichannel seismic reflection study; Tectonophys. 321 189-218.

Oktay F Y, Gökaşan E, Sakınç M, Yaltırak C, İmren C and Demirbağ E 2002 The effect of North Anatolian fault zone to the latest connection between Black Sea and sea of Marmara; Mar. Geol. 190 367-382.

Parke J R, Minshull T A, Anderson G, White R S, McKenzie D P, Kuşçu İ, Bull J M, Görür N and Şengör A M C 1999 Active faults in the sea of Marmara, western Turkey, imaged by seismic reflection profiles; Terra Nova 11223 227.

Polonia A, Gasperini L, Amorosi A, Bonatti E, Bortoluzzi G, Çăgatay N, Capotondi L, Cormier M H, Görür N, McHugh C and Seeber L 2004 Holocene slip rate of the North Anatolian fault beneath the sea of Marmara; Earth Planet. Sci. Lett. 227 411-426.

Ryan W B F, Pitmann W C, Major C O, Shimkus K, Moskalenko V, Jones G A, Dimitrov P, Görür N, Sakınç $\mathrm{M}$ and Yüce H 1997 An abrupt drowning of the Black Sea shelf; Mar. Geol. 138 119-126.

Ryan W B F, Major C, Lericolais G and Goldstein S L 2003 Catastrophic flooding of the Black Sea; Annu. Rev. Earth Planet. Sci. 31 525-554.

Sarıtaş H 2013 Mapping and exploration of gas and possible gas hydrate accumulation in western high, sea of Marmara in the light of 2D-3D high resolution seismic data; PhD Thesis, Dokuz Eylül University, The Graduate School of Natural and Applied Sciences, Izmir.

Şengör A M C, Görür N and Şaroğlu F 1985 Strike-slip, faulting and related basin formation in zones of tectonic escape: Turkey as a case study; In: Strike-slip deformation, basin formation, and sedimentation (eds) Biddle $\mathrm{K}$ T and Christie-Blick N, Soc. Econ. Paleontol. Mineral. Spec. Publ. 37 227-264.

Şengör A M C, Tüysüz O, İmren C, Sakınç M, Eyidoğan H, Görür N, Pichon X L and Rangin C 2005 The north Anatolian fault: A new look; Annu. Rev. Earth Planet. Sci. 33 37-112.

Siyako M 2006 Lignitic sandstones of the Trakya Basin; Mineral Res. Exp. Bull. 132 63-72.

Sperling M, Schmiedl G, Hemleben C, Emeis K C, Erlenkeuser H and Grootes P M 2003 Black Sea impact on the formation of eastern Mediterranean sapropel S1? 
Evidence from the Marmara Sea; Palaeogeogr. Palaeoclimatol. Palaeoecol. 190 9-21.

Stanley D J and Blanpied C 1980 Late quaternary water exchange between the eastern Mediterranean and the Black Sea; Nature 285 537-541.

Stein R S, Barka A A and Dieterich J H 1997 Progressive failure on the north Anatolian fault since 1939 by earthquake stress triggering; Geophys. J. Int. 128 594-604.

Taymaz T, Jackson J and McKenzie D 1991 Active tectonics of the north and central Aegean Sea; Geophys. J. Int. 106 433-490.

Tur H, Hoşkan N and Aktaş G 2015 Tectonic evolution of the northern shelf of the Marmara Sea (Turkey): Interpretation of seismic and bathymetric data; Mar. Geophys. Res. 36 1-34.

Corresponding editor: Munukutla RAdHAKRISHna
Tüysüz O, Barka A A and Yiğitbaş E 1998 Geology of the Saros Graben and its implications for the evolution of the North Anatolian fault in the Ganos-Saros region, northwestern Turkey; Tectonophys. 293 103-126.

Vardar D, Alp H and Alpar B 2018 Seismic stratigraphy and depositional history of the Büyükçekmece Bay since Latest Pleistocene, Marmara Sea, Turkey; J. Earth Syst. Sci. 12713.

Vidal L, Menot G, Joly C, Bruneton H, Rostek F, Çă̆atay N, Major C and Bard E 2010 Hydrology in the sea of Marmara during the last $23 \mathrm{ka}$ : Implications for timing of Black Sea connections and sapropel deposition; Paleoceanography 25 1-16.

Yaltirak C 2002 Tectonic evolution of the Marmara sea and its surroundings; Mar. Geol. 190 493-529. 